\title{
Marketing Mix Practices in the Cultural Industry
}

\author{
Dr. Ali Shahhosseini \\ $\mathrm{PhD}$ in cultural management and planning from Faculty of Management and Economics \\ Science and Research Branch, Islamic Azad University, Tehran, Iran
}

Fateme Tohidy Ardahaey (Corresponding author)

$\mathrm{PhD}$ student in cultural management and planning at Faculty of Management and Economics

Science and Research Branch, Islamic Azad University, Tehran, Iran

E-mail: ftohidy.ardahaey@gmail.com

Received: December 29, 2010 Accepted: March 5, 2011 doi:10.5539/ijbm.v6n8p230

\begin{abstract}
This research studies marketing mix and its elements - especially the Four Ps including product, price, place and promotion- in the cultural industry. It reviews the concept of marketing mix and deals with its elements and then, studies in brief the impact of each element on the success of cultural industry.

Since the development of cultural and art activities is significantly considered in the globalization process today, marketing managers in cultural fields should investigate deeply the target cultural consumers' understanding, preferences and perception. It is understandable because marketing strategies can indeed determine appropriate strategies in cultural fields to offer the best services in the most beneficiary way for both parts of businesses. Hence, taking account the importance of its elements in absorbing cultural buyers and keeping them satisfied should be the central concern for all marketing managers in the cultural market.
\end{abstract}

Keywords: Marketing, Culture, Cultural industry, Cultural goods, Marketing strategy, Marketing mix

\section{Introduction}

Culture in its specific meaning could be known as the production and consumption of goods and cultural services or the contribution in cultural production (Nokoomaram et al., 2010). Based on a review from UNESCO, during the two last decades of the twentieth century, international trade of cultural goods has quadrupled. Between the years 1998-1980 the volume of exchange of books, magazines, music production, visual arts, film, photography, radio and television, games and sporting goods has reached from 95,340 million dollars to 387,927 million dollars (Amiri et al., 2010). However, this exchange has happened somewhere between a limited number of countries; for example, 4 / 55 percent of total global has been in Japan, America, Germany and Great Britain in 1990. This trend did not change much during the decade of 90, although new actors appeared in the field, such as China, which had the third place in 1998 as the Exporter country of the world. Five above mentioned large countries owned 53 percent of exports of cultural goods (Group of Writers, 2001). The few countries with a history of cultural industry production offer high quality standards throughout the production process, a track record in original production and the presence of global media and entertainment corporations. These factors will strengthen existing export markets and contribute to the development of new niches in world markets(Note 1). A major reason for these conditions is the utilization of the software power by a series of countries for influencing other countries, without utilizing any force and hardware power (Amiri et al., 2010).

Marketing mix, also known as the Four Ps, is probably the most famous marketing term. Its elements (product, price, place and promotion) are the fundamental and tactical components of a marketing plan.

Many authors argue that understanding the customer attitude toward 4Ps marketing mix is important (Purnomo et al., 2010). Constantinides (2006) emphasizes that marketing mix is a framework of the dominant marketing management paradigm to identify market development, environmental changes and trends. Several studies confirm that the 4Ps is indeed the trusted conceptual platform of practitioners dealing with operational marketing issues (Romano and Ratnatunga, 1995; Coviello et al., 2000). The wide acceptance of the 4Ps among field marketers is the result of their profound exposure to this concept during college years, since identifying the 4Ps as the controllable parameters is likely to influence the consumer buying process and decisions (Brassington and Pettitt, 2003; Soekartawi, 2005).

As the development of cultural export has both economical and cultural value and designing a model for the cultural export appropriate with the cultural system of the country can lead to a more healthy and rational consumption of cultural goods (Ballantyne, 2003), this research is to identify the most influential marketing factors in the development of export of cultural goods. 


\section{Marketing Strategy for Cultural Industry}

Many marketing researchers have broadly argued marketing strategy to be a concept built on robust platform of segmentation, targeting and positioning (Ferrell et al., 2002; Walker et al., 2001). Marketing strategy requires decisions about the specific target of customers. Besides, marketing mix may be developed to target market by positioning it suitably in a superior way.

Understanding the customers' needs and wants induces companies to realize that no two buyers are ever exactly the same. This heterogeneity in needs and wants drive companies to look for distinctive groups of customers with rather homogeneous needs and expectations which, when aggregated, represent potential target markets (Dibb et al., 1998) and this is even more intense when it comes to marketing of cultural goods as identifying every individual's elegance and taste is such a difficult task.

In this context, the study of the effectiveness of the marketing tools is essential for an appropriate marketing strategy. Appropriateness of marketing strategies may be viewed as the congruence of market offerings of a set of products and its corresponding consumer perception among its target segment. More the target segment is able to understand and believe the cues (Richardson et al., 1994) communicated by the firms through marketing mix, more is the effectiveness of the marketing strategies. In fact, the goal to satisfy customers drives market oriented companies to go as far as one-to-one marketing for their relatively larger customers (Dalgic, 2000).

Cultural and art activities are divided into the following different culture and art sectors: Books and reading, art, movies and printed matters such as magazines, newspapers and etc. As far as the company's products are concerned, continuous innovation and new product development have both been associated with market orientation (Witcher, 1985; Houston, 1986; Hooley et al., 1990). Many of the factors underlying the success of new products are associated with the "goodness-of-fit" dimension of success, i.e. the company's ability to understand the needs of the market and cater for them (Cooper and Kleinschmidt, 1987).

However, when it comes to the composition of the product portfolio of cultural goods companies, one could realize that there are various examples of policies spearheaded by different sectors to promote the diversity of cultural expressions through associative strategies. Many of these policies strategically integrate new technologies with networking to develop alternative forms of distribution that enable dissemination to niche markets, non-mainstream forms of expression, or those forms created by minority communities or groups.

Some cultural policies focus on the interdependent relationship between the social and economic dimensions of culture. Such holistic policies would be ideal for promoting sustainability in cultural development. Some interventions aim in particular at fostering this type of interrelation.

Over the past few decades, many creators, artists' collectives and cultural groups have sought strategies for sociocultural mobilization with this approach in mind, combining access, empowerment and creation, for example, the promotion of subaltern artists and groups through communitary action, education and public diffusion. These projects open informal spaces or others linked to formal institutions such as workshops for the professionalization of artists, education for employment, and the creation of economic opportunities in the cultural industries.

The importance of the transformations brought about by the expansion of marketing techniques in the public realm should also be emphasized, as should the power of the new media. Today, cultural and social communication initiatives increasingly connect individuals and communities in ways that would have been unlikely a few years ago: art and entertainment celebrities work with multilateral agencies to raise consciousness or funding for a variety of causes; mainstream artists now enter alternative global consumption circuits; and municipalities work with private international actors to generate large-scale cultural content or programs to enhance visibility.

These types of joint action generate complex effects that condition the ways in which local content and actors can have an impact on their immediate surroundings. Often, these actions run the risk of losing the power to shape local cultural agendas. The risks are quite evident in cases in which the State has little or no role in funding public media, establishing public strategies, or lacks the capacity to regulate or negotiate among diverse interests.

One of the main challenges for the State in its role in cultural development is the ability to promote the public interest, democratize social representation, and ensure a greater diversity of actors at various administrative levels (local, municipal, national and international scales).

Market and citizen participation manifest themselves in increasingly complex and intimate ways, both in terms of mutual empowerment opportunities and contradictions and conflicts of interest. (Note 2)

\section{Marketing Mix Practices and Cultural Industry}

The marketing mix and the 4 Ps of marketing are often used as synonyms for each other. In fact, they are not necessarily the same thing (Note 3).

The marketing mix refers to variables that a marketing manager can control to influence a brand's sales or market share. Traditionally, these variables are summarized as the Four Ps of marketing: product, price, promotion, and 
place (i.e., distribution; McCarthy, 1996). Product refers to aspects such as the firm's portfolio of products, the newness of those products, their differentiation from competitors, or their superiority to rivals' products in terms of quality. Promotion refers to advertising, detailing, or informative sales promotions such as features and displays. Price refers to the product's list price or any incentive sales promotion such as quantity discounts, temporary price cuts, or deals. Place refers to delivery of the product measured by variables such as distribution, availability, and shelf space (Tellis, 2006).

The 4Ps model is just one of many marketing mix lists that have been developed over the years. And, whilst the questions we have listed above are keys, they are just a subset of the detailed probing that may be required to optimize your marketing mix.

Amongst the other marketing mix models have been developed over the years is Boom and Bitner's 7Ps, sometimes called the extended marketing mix, which include the first 4 Ps, plus people, processes and physical layout decisions.

Another marketing mix approach is Lauterborn's 4Cs, which presents the elements of the marketing mix from the buyer's, rather than the seller's, perspective. It is made up of Customer needs and wants (the equivalent of product), Cost (price), Convenience (place) and Communication (promotion) (Note 4).

Cultural policies to promote diversity of cultural expressions today must deal with numerous factors and needs, some of which concern the right of all groups to their forms of expression, and others strictly with business feasibility and the possibility of marketing on a global scale. These different factors may be difficult to reconcile but they are complementary as none can survive and be managed without referring to or involving the other (Note $5)$.

From the perspective of production development, it is frequently stated that cultural expressions need to find their market in order to survive, but it is also the case that the sacrificing of cultural content with little market value lowers the value of cultural production overall. From the perspective of rights to and processes of identity construction, culture generates services that cannot be governed exclusively by the market, especially in view of the marginality of subaltern groups. Nevertheless, it is almost impossible to think of cultural practices and consumption today without involving the market in some way(Note 6).

For marketers in the cultural industry it is important to identify the factors influencing consumers' purchasing. Cultural factors are essentially important in selection of the two elements of "place" and "product". For example, someone brought up in an environment that values art would be more likely to buy artistic products. Even it may be important considering customers in terms of their sub-culture. One may be surrounded by people who not only value art but place a higher priority on paintings as opposed to the music. As a result, they will be more likely to buy paintings rather than musical instrument.

"Pricing" the artistic products and activities should also follow a logic trend. This practice may be done through some standards set among artists of the same class or by the very artist creator of his work. In general, as it can be seen, due to the difference

\section{Ethics and Marketing in Cultural Industry}

While the company's reputation is derived from perceptions of all stakeholders (Whetten \& Mackey, 2002, p. 401), Wartick (2002, p. 377) suggests it is pragmatic to focus on just the immediate customers as they usually are the group that have the major influence. Greyser (1996) advocates that the core component of corporate reputation is a corporate brand. Moreover, he also discovers that there is an interesting relationship between corporate reputation and corporate performance, especially from social performance. Thus, concerning ethical brands, which promise social performance as well as economic and environmental performance, it is clear that there is a close link between ethical branding and corporate reputation. Cretu and Brodie (2005) used the customer value methods developed by Gale (1994) and Rust et al., (1995). Cretu and Brodie (2005) extended their work by paying explicit attention to the influences on company reputation. Consequently, the feeling of ethical branding via corporate reputation is expected to enhance customer loyalty.

According to Paluszek (2006), ethical brand can be a strategic differentiation to provide a superior value to customer by high standards of business integrity and social responsibility. Through this strategic element, a company can provide a long-term corporate value to enhance the commitment of the customers.

In other words, ethical brands that recognize the environment, social, and economic responsibility and also show a commitment to 'doing the right thing', create added value to both firms and customers. Brands play the key role in enhancing the value of products and protecting products from being imitated by competitors (Aaker, 1991). Therefore, a strong brand with ethical characteristics is counted as a valuable asset for a company.

Actually, a set of factors could encourage business firms in repeated purchasing behavior. This means that without a good image of company reputation, repeated behavior is not guaranteed. As several studies identified, satisfaction was necessary but not sufficient. It required other factors including 'ethical brand' related to company reputation as complementary to the explanatory variables (Fan, 2005; Paluszek, 2006).

Thus it may reasonably be assumed that ethical branding will affect corporate reputation and gain brand loyalty. 
By correlating to corporate reputation, it is very important to conduct in depth research, especially to explore relationships with brand loyalty. The concept of 'ethical brand', which is an integrated element of the new paradigm, is as an additional variable included in the model (Paluszek, 2006). The constructs that either directly or indirectly (via both ethical brand and company reputation) affect brand loyalty of an industrial buyer.

Brands are now seen as the key success factor in order to achieve competitive advantages for firms through differentiation. These competitive advantages may be achieved by ethical brands in terms of a brand being one construct in addition to the existing variables to set up corporate reputation and loyalty(Note 7).

\section{Conclusion}

The development of cultural and art activities is significantly considered in the globalization process today. This implies that any kind of activity which pursues the growth of production and supply of cultural and art goods and services and also the growth of consumers needs to be paid attention in terms of marketing and offering these services in a proper manner.

Marketing mix helps to define the marketing elements for successfully positioning market offer. As it has been mentioned in the literature of the research, one of the best known models in marketing mix is the Four Ps, which helps to define the marketing options in the cultural industry in terms of product, place, price and promotion. However quit different the cultural goods and services are from mere physical goods and services, this model, as the most common one, can be used when planning to offer a new venture or product, or evaluating an existing offer, to optimize the impact with the target market.

Planning the marketing mix is a key task in marketing management. Careful and prudent planning requires that marketing managers considering the way markets have responded to the marketing mix in the past. This is even more considerable in cultural marketing, as in cultural market the number of buyers is limited in cultural taste, background and setting, and keeping them satisfied for continuous business relationship is of significant importance. Of course, the underlying assumption is not that merely the past predicts the future with certainty but that it contains valuable experiences that might help enlighten the future.

Marketing managers in cultural fields should investigate deeply the target cultural consumers' understanding, preferences and perception. It is understandable because marketing strategies can indeed determine appropriate strategies in cultural fields to offer the best services in the most beneficiary way for both parts of businesses.

All the elements of marketing mix and mostly the Four P's - product, price, place, and promotion — should work together to help to design the best marketing strategies in the cultural market. Because, often decisions on one element especially product and pricing, will influence the choices available in others.

Marketing is a part of every industry's venture that will never end in the cycle of business practices. Selecting an effective mix for the market will sure take time and effort, but these will pay off as an industry satisfies its customers and create a profitable business. Once an industry has a good marketing mix - the right product at the right price, offered in the right place and promoted in the right way - it will need to continue to stay on top of market changes and adopt its marketing mix as necessary. Hence, taking account the importance of its elements in absorbing cultural buyers and keeping them satisfied should be the central concern for all marketing managers in the cultural market.

\section{References}

Amiri S R S, Kavousy E and Hosseinzadegan Z. (2010). The Role of Export of Cultural Goods in Cultural Development of Iran. European Journal of Social Science, Vol. 14, No. 4.

Ballantyne, David. (2003). A relationship- mediated theory of internal marketing. European journal of marketing, Vol. 37. No.9.

Brassington F, \& Pettitt S. (2003). Principles of Marketing, Third Edition. Prentice Hall/Financial Times. New Jersey.

Constantinides E. (2006). The Marketing Mix Revisited: Towards the 21st Century Marketing. J. Mark Manag, 22: 407-438.

Cooper, R., and Kleinschmidt, E. (1987). Success factors in product innovation. Industrial- Marketing Management, Vol. 16, August, pp. 215-23.

Coviello NE, Brodie RJ, \& Munro HJ. (2000). An investigation of marketing practice by firm size. J. Bus Venturing, 15: 523-545.

Dalgic, T. (2000). "MO and its implications", in Blois, K. (Ed.), The Oxford Textbook in Marketing, Oxford Press, Oxford, pp. 20-36.

Dibb, S., Simkin, L., Pride, W., and Ferrell, O. (1998). Marketing: Concepts and Strategies. Houghton Mifflin, Boston, MA.

Ferrel OC, Hartline, MD, \& Lucas GH Jr. (2002). Marketing Strategy, $2^{\text {nd }}$ ed. Thomson southwestern, Bangalore, p.74. 
Flint D, Woodruff R, \& Gardial SF. (1997). Customer Value Change in Industrial Marketing Relationships. A Call for New Strategies and Research. Ind Mark Manag, 26: 163 -175.

Gale, B. T. (1994). Managing customer value: Creating quality and service that customers can see. New York' The Free Press.

Greyser, S. A. (1996). Cause-Related Marketing: Finding the Ideal Corporate Alliance. Corporate Social Responsibility: winter.

Group of Writers. (2001). World Report on Culture (Group of Translators), National Commission for UNESCO, Tadbir Institute of Economic Research.

Hooley, G., Lynch, J., and Shepherd, J. (1990). The marketing concept: putting the theory into practice. European Journal of Marketing, Vol. 24 No. 9, pp. 7-23.

Houston, F. (1986). The marketing concept: what it is and what it is not. Journal of Marketing, Vol. 50 No. 2, pp. 23-39.

McCarthy, J. (1996). Basic marketing: A managerial approach (12th ed.). Homewood, IL: Irwin.

Nikoomaram, H., Soltani, M., and Kavousy, E. (2010). The Cession of Cultural Activities to the Private Sector in Iran. European Journal of Social Sciences, Volume 12, Number 4.

Paluszek, J. (2006). Ethics and brand value: Strategic differentiation. Santa Clara University, Markkula Center for Applied Ethics.

Purnomo S. H, Lee Y. H and Soekartawi. (2010). Why is understanding customer attitude toward 4Ps marketing mix important? The case of the livestock input industry in Indonesia. Journal of Development and Agricultural Economics, Vol. 2(4), pp. 107-114.

Richardson SP, Dick SA and Jain AK. (1994). Extrinsic and intrinsic cue effects on perceptions of store brand quality. J. Mark, 58: 28-36.

Romano C, \& Ratnatunga J. (1996). The Role of Marketing. Eur J. Mark, 29: 9-30.

Rust, R. T., Zahorik, A. J., \& Keiningham, T. L. (1995). Return on Quality (ROQ): Making service quality financially accountable. Journal of Marketing, 59(2), 58-70.

Shaw V. (1995). Successful Marketing Strategies, a Study of British and German Companies in the Machine Tool Industry. Ind. Mark Manag, 21: 329-339.

Soekartawi. (2005). Marketing Management for Agricultural Products: Theory and Its Application. RajaGrafindo Persada Press, $3^{\text {rd }}$ Edition, Jakarta, (ISBN: 979-421-207-5).

Tellis G J. (2006). Modeling Marketing Mix, 24-Grover.qxd, University of Southern California, P. 506: [Online] Available: http://www-bcf.usc.edu/ tellis/mix.pdf

Walker OC Jr., Boyd HW Jr., \& Larreche JC. (2001). Marketing Strategy. Tata McGraw Hill, New Delhi pp. 12-13.

Wartick, S. L. (2002). Measuring corporate reputation: Definition and data. Business and Society, 41(4), 371392 .

Whetten, D. A., and Mackey, A. (2002). A social actor conception of organizational identity and its implications for the study of organizational reputation. Business and Society, 41(4): 393.

Witcher, B. (1985). Innovation and marketing. The Quarterly Review of Marketing, Vol. 10 No. 2, pp. 14-24.

http://unesdoc.unesco.org/images/0015/001598/159869e.pdf

http://www.mindtools.com/pages/article/newSTR_94.htm

http://eprints.um.edu.my/831/1/SulaimanAli_Final.pdf

Notes

Note 1. http://unesdoc.unesco.org/images/0015/001598/159869e.pdf

Note 2. http://unesdoc.unesco.org/images/0015/001598/159869e.pdf

Note 3. http://www.mindtools.com/pages/article/newSTR_94.htm

Note 4. http://www.mindtools.com/pages/article/newSTR_94.htm

Note 5. http://unesdoc.unesco.org/images/0015/001598/159869e.pdf

Note 6. http://unesdoc.unesco.org/images/0015/001598/159869e.pdf

Note 7. http://eprints.um.edu.my/831/1/SulaimanAli_Final.pdf 